\title{
Heterogeneous magnesium isotopes of the Cenozoic mantle-derived volcanics on SE Tibetan Plateau: Implication for the subduction of Indian Plate
}

H.S. $\mathrm{LEI}^{1}$, Z.D. ZHAO ${ }^{1 *}$, F.Z TENG ${ }^{2}$, D. LIU ${ }^{1}$, QIAN MA ${ }^{1}$ AND DI-CHENG ZHU ${ }^{1}$

${ }^{1}$ State Key Laboratory of Geological Processes and Mineral Resources, and School of Earth Science and Resources, China University of Geosciences, Beijing 100083, P. R. China (*correspondence: zdzhao@cugb.edu.cn)

${ }^{2}$ Isotope Laboratory, Department of Earth and Space Sciences, University of Washington, Seattle, Washington 98195, USA (fteng@u.washington.edu)

The mantle metasomatism caused by Indian-Eurasian continent collision and succedent subduction of Indian Plate beneath Southeastern Tibetan Plateau, are essential for the postcollisional mantle-derived volcanic rocks. We present new element compositions and $\mathrm{Sr}-\mathrm{Nd}-\mathrm{Mg}-\mathrm{Pb}$ isotopes of EoceneOligocene (36.6 29.0 Ma) volcanics sampled from Maliqing, Runanshao and Houshan. These samples vary from low- $\mathrm{SiO}_{2}$ and high-MgO picrite to high- $\mathrm{SiO}_{2}$ and low-Mg trachandesite $\left(\mathrm{SiO}_{2}=43.43 \sim 63.56 \mathrm{wt} \% ; \mathrm{MgO}=2.65 \sim 27.57 \mathrm{wt} \%\right)$. They mainly show $\mathrm{Nb}-\mathrm{Ta}-\mathrm{Ti}$ negative anomalies, enriched $\mathrm{Sr}-\mathrm{Nd}$ isotopes $\left({ }^{87} \mathrm{Sr} /{ }^{86} \mathrm{Sr}=0.7054 \sim 0.7076 ; \varepsilon \mathrm{Nd}=-5.2 \sim-1.8\right)$ and heavy $\mathrm{Mg}$ isotopes $\left(\delta^{26} \mathrm{Mg}=-0.31 \sim-0.13 \%\right)$. It suggests that these rocks were possibly derived from metasomatized lithospheric mantle, which had been enriched by subduction-related fluids.

According to previous studies, the Tengchong volcanics $(17.8 \sim 0.003 \mathrm{Ma})$ consist of trachybasalt, basaltic trachyandesite and trachyandesite. They exhibit lower $\mathrm{K}_{2} \mathrm{O} / \mathrm{Na}_{2} \mathrm{O}$ ratios $(0.43 \sim 1.23)$ and lighter $\mathrm{Mg}$ isotopes $\left(\delta^{26} \mathrm{Mg}=-0.51 \sim-0.27 \%\right.$ ), which were proposed as the product of the partial meling of carbonated lithospheric mantle [1]. Therefore, lithospheric mantle beneath the SE Plateau recorded by these two periods of volcanics experienced distinct metasomatism. Thus, a subduction-induced mantle enrichment had been taken place between 29.0 17.8 Ma. As Neo-Tethyan Oceanic slab had broken off before $40 \mathrm{Ma}$ [2], this enrichment indicates the subduction of Indian Plate, which are also recorded by the shifting of $\mathrm{Pb}$ isotopes from Tengchong volcanics towards Indian continent. Our results reveal that Indian plate had subducted beneath SE Tibetan Plateau between $29.0 \sim 17.8 \mathrm{Ma}$.

[1] Liu (2017) J. Geophys. Res 122, 9729-9744. [2] Xu (2008) Chem.Geol 255, 439-453 